\title{
Relato oficial da ocorrência de Olivea tectonea em teca (Tectona grandis) no Brasil.
}

\author{
Solange Maria Bonaldo ${ }^{1}$, Ane Caroline Barceli ${ }^{1}$, Rogelho Alexandre Trento ${ }^{1}$, Francielli Gasparotto ${ }^{2}$ e Camila Taffarel $^{1}$
}

${ }^{1}$ Instituto de Ciências Agrárias e Ambientais (ICAA)/Campus de Sinop/UFMT, Av. Alexandre Ferronato, 1.200 CEP. 78.557-267, Sinop, MT, Brasil. ${ }^{2}$ Centro Universitário de Maringá. Av. Guedner, 1.610 CEP. 87050-390 - Maringá, PR, Brasil.

Autorizado a divulgação pelo MAPA, em 10/03/2011. Processo: 21024-002237/2009-73

Autor para correspondência: Solange Maria Bonaldo (sbonaldo@ufmt.br).

Data de chegada: 03/04/2011. Aceito para publicação em: 03/06/2011.

1750

A teca (Tectona grandis Linn. F.) é uma espécie arbórea de grande porte com origem asiática bastante utilizada para áreas de reflorestamento. Possui tronco retilíneo o que facilita os tratos culturais e também é uma planta rústica, com grande rendimento, rápido crescimento e certa tolerância ao calor, pragas e doenças. No Brasil está presente em diversas regiões do Mato Grosso onde é cultivada para a extração da madeira utilizada em construções navais, pontes, decorações, carpintaria e principalmente para móveis, devido à excelente qualidade, resistência, durabilidade e beleza.

Em maio de 2009 verificou-se a presença de sintomas de ferrugem (Figura 1A), bem como a presença dos sinais do patógeno (Figura 1B), em mudas e plantas adultas de diferentes idades localizadas no município de Sinop/MT. Os sintomas, na superfície adaxial da folha, iniciam com pequenas manchas necróticas que coalescem e podem atingir toda a superfície foliar, levando a folha a apresentar um aspecto de queima, com conseqüente desfolha da planta. Na superfície abaxial da folha, correspondente a área necrosada, foram encontradas urédias pulverulentas (Figura 1C), de coloração amarelo laranja e com intensa produção de uredósporos (Figura 1D).

O exame microscópio do material evidenciou a presença de uredósporos ovóides, unicelulares, equinulados, com coloração amarelo-alaranjado, apresentando tamanho variando de 12,3-24,8 x 14,7-24,8 $\mu \mathrm{m}$ e ausência de teliósporos. De acordo com essas características, o patógeno foi identificado como Olivea tectonea (Mulder JL.; Gibson IAS., CMI Descriptions of Pathogenic Fungi and Bacteria, No. 365, Commonwealth Mycological Institute: Kew, 1973) considerada até então praga exótica no Brasil, sendo este o primeiro relato oficial da ocorrência deste fitopatógeno no país.

A ferrugem da teca é uma doença relatada no Sul, Oriente e Sudeste Asiático (Su-See L. Australasian Plant Pathology. v.8, p.283-291, 1999) e diversos outros países: Panamá, Costa Rica (Arguedas M., Kuru: Revista Forest. v.1, p.1-6, 2004), Equador (European and Mediterranean Plant Protection Organization (EPPO), 2005), México (NAPPO Pest Alert - Official Pest Reports for Mexico, 2005), Colômbia (Céspedes PB; Yepes MS. Revista Facultad Naltionalde Agronomia, Medellín, v.60, p.3645-3655, 2007), Cuba (Perez M, Lopez MO, Marti O., New Disease Reports v.17, p.32, 2008), Austrália (Daly AM, Shivas RG, Pegg GS, Mackie AE., Australasian Plant Disease Notes v.1, p.25-26, 2006).

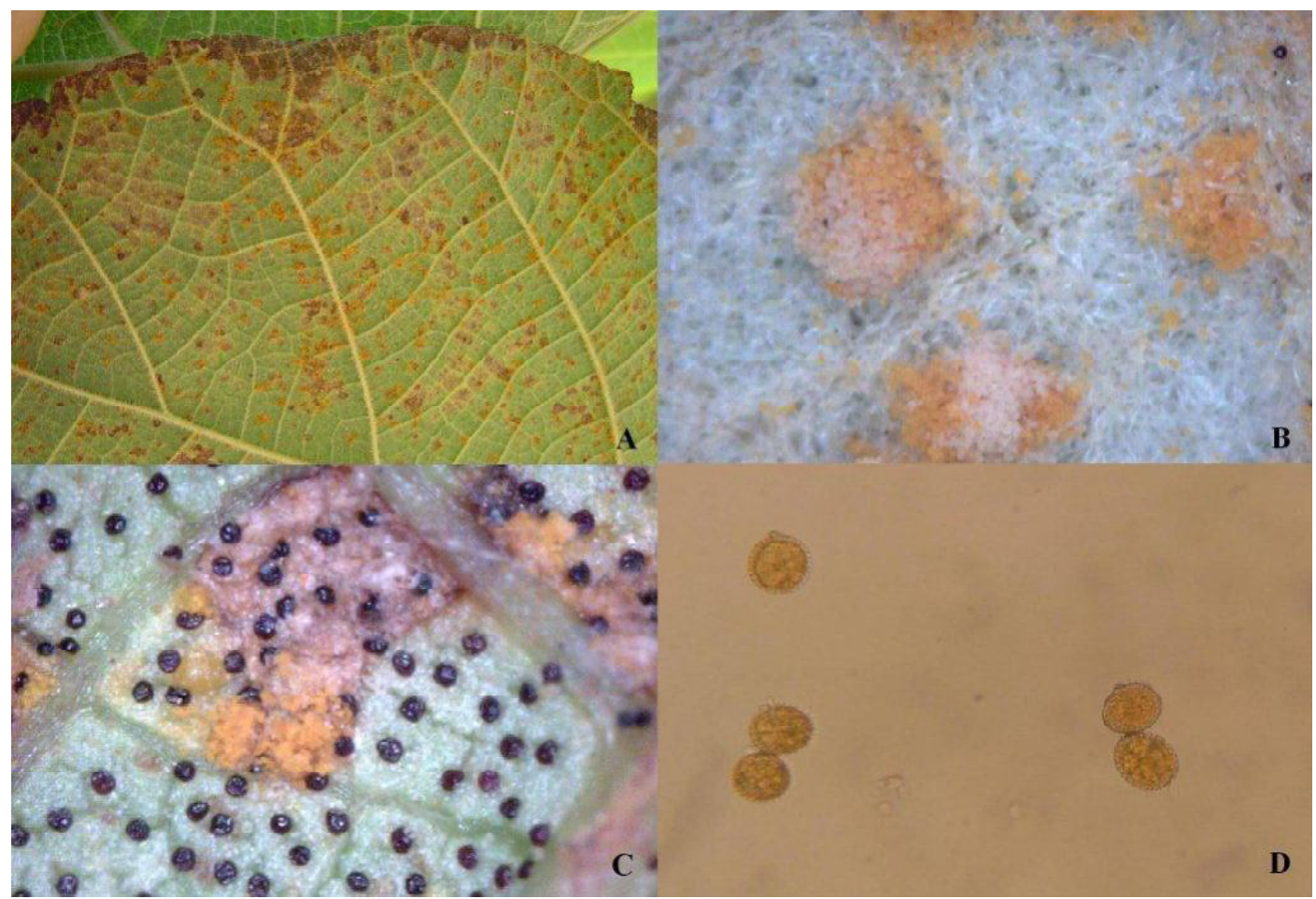

Figura 1. Sintomas de ferrugem em plantas adultas (A); Pústulas com intensa esporulação na parte abaxial da folha (B) e detalhe da urédia (C); Uredósporos de Olivea tectonea (D). 